\title{
The Lack of Effect of Basic and Acidic Fibroblast Growth Factors on the Naturally Occurring Death of Neurons in the Chick Embryo
}

\author{
Ronald W. Oppenheim, ${ }^{1}$ David Prevette, ${ }^{1}$ and Forrest Fuller ${ }^{2}$ \\ 'Department of Neurobiology and Anatomy, and Neuroscience Program, Bowman Gray Medical School, Wake Forest \\ University, Winston-Salem, North Carolina 27157-1010 and ' ${ }^{2}$ California Biotechnology, Inc., Mountain View, California 94043
}

\begin{abstract}
In vivo treatment of developing chick embryos with acidic and basic fibroblast growth factors (aFGF and bFGF) failed to affect the differentiation and survival of several populations of developing neurons in the CNS and PNS. All of the neuronal populations examined are known to undergo naturally occurring cell death, and they include spinal and cranial motoneurons, dorsal root ganglia, sympathetic ganglia, nodose ganglia, ciliary ganglia, and sympathetic preganglionic neurons in the PNS, as well as the accessory oculomotor nucleus, the isthmo-optic nucleus, and the brainstem auditory nuclei laminaris and magnocellularis in the CNS. Despite the lack of effect of bFGF on neuronal survival and differentiation, in vivo treatment increased the serum levels of bFGF and stimulated the proliferation of non-neuronal cells in the spinal cord. Therefore, although the administration of exogenous FGF to the developing chick embryo in vivo clearly has some biological activity in the CNS, it was nonetheless ineffective in promoting neuronal survival or differentiation. These data do not support the idea that FGF is a physiologically relevant neurotrophic agent in the developing avian nervous system.
\end{abstract}

The heparin-binding family of growth factors has been suggested to regulate a variety of cellular and molecular events during vertebrate development (Burgess and Macaig, 1989). For example, some of the best-studied members of this family, basic and acid fibroblast growth factor (bFGF and aFGF), are reported to affect the induction, mitotic division, survival, morphology, cell-cell interactions, and differentiation of many mesenchymal and neuroectoderm derivatives (Walicke, 1989; Gospodarowicz, 1990; Westermann et al., 1990; Wagner, 1991). Notable among the myriad reported effects of aFGF and bFGF on neuroectoderm-derived cells (neurons and glia) is the ability of these agents to promote the survival of different types of developing neurons in vitro (e.g., Kalcheim, 1989; Walicke, 1989; Eckenstein et al., 1990; Matsuda et al., 1990; Westermann et al., 1990; Biederman et al., 1991; Sweetnam et al., 1991), including spinal

\footnotetext{
Received Nov. 26, 1991; revised Feb. 12, 1992; accepted Feb. 14, 1992.

This work was supported by NIH Grant NS20402 and a grant from the Amyotrophic Lateral Sclerosis Foundation. We are grateful to Carmen Bryant and Trina Schenerman of California Biotechnology, Inc. for their help in preparing the bFGF and for conducting the FGF radioimmunoassay. We also thank Dr. Ralf Pettersson for supplying the human recombinant aFGF, and Barbara Cordell of California Biotechnology for providing the human recombinant bFGF.

Correspondence should be addressed to R. W. Oppenheim, Ph.D., Department of Neurobiology and Anatomy, Bowman Gray Medical School, Wake Forest University, Winston-Salem, NC 257157-1010.

Copyright (C) 1992 Society for Neuroscience $0270-6474 / 92 / 122726-09 \$ 05.00 / 0$
}

cord motoneurons (MNs; Unsicker et al., 1987; Arakawa et al., 1990; but see Dohrmann et al., 1987; Bloch-Gallego et al., 1991). FGFs have also been reported to prevent cell death and other regressive changes induced by axotomy, injury, or genetic mutations in retinal ganglion cells (Sievers et al., 1987; Mattson and Rychlik, 1990), photoreceptors (Faktorovich et al., 1990), hippocampal neurons (Barotte et al., 1989), preganglionic neurons (Blottner et al., 1989), dorsal root ganglion (DRG) cells (Otto et al., 1987), and dopaminergic neurons (Otto and Unsicker, 1990) of adult animals. Thus, FGF may be a trophiclike agent that regulates both the normal survival of developing neurons and the survival and maintenance of mature neurons following injury.

Because we have been interested in the trophic requirements of developing spinal cord MNs in vivo, we have begun to screen a number of putative neurotrophic agents, including FGF, for their effectiveness in reducing the normal cell loss observed during naturally occurring MN death (Oppenheim, 1991). In virtually all vertebrates that have been examined, approximately one-half of all postmitotic spinal MNs undergo degeneration and cell death during embryogenesis. The survival of a proportion of postmitotic MNs during this period is partly regulated by neuron-target interactions, and the amount of survival can be increased by in vivo treatment with muscle-derived as well as by non-muscle-derived molecules (Oppenheim et al., 1988, 1991; McManaman et al., 1990). In the present study, we have examined the effectiveness of FGFs in promoting the in vivo survival of spinal $M N s$ as well as the survival of a variety of other neuronal populations that are known to undergo naturally occurring neuronal death in the chick embryo.

Portions of this work have been published previously in abstract form (Oppenheim et al., 1990).

\section{Materials and Methods}

Embryos and FGF treatment. Eggs were obtained as a generous gift from Hubbard Farms, Statesville, NC. The eggs were incubated in the laboratory at $37^{\circ} \mathrm{C}$ and $60 \%$ relative humidity and were automatically turned several times per day. On the day before they were to be used in an experiment, the eggs were removed from the incubator and a small window was made on the side of the egg over the embryo thereby exposing the vascularized chorioallantoic membrane (CAM). The window was then sealed with Parafilm (Sigma) and the egg returned to an incubator, where they were no longer turned. For most experiments reported here, embryos were treated daily from embryonic day 6 (E6) to E9 or from E9 to E13-E14 with aFGF or bFGF and then killed on E10 or E14-E15. In one experiment, embryos were treated daily from E8 to E13. In all of the above experiments, treatment consisted of daily application of either human recombinant aFGF, which was provided by Ralf Pettersson (Cao and Pettersson, 1990), or human recombinant bFGF, which was provided by California Biotechnology, Inc. (Mountain 
View, $\mathrm{CA}$ ), or of control substances (saline, heparin, or cytochrome $\mathrm{C}$ Sigma), onto the CAM. Although administration of putative trophic agents and other substances onto the CAM has been repeatedly shown to be an effective mode of treatment of chick embryos in ovo (e.g. Oppenheim et al., 1991), in one group of embryos FGF or control solutions were injected directly into the vitreous of the right eye in ovo on E10 or E11 and embryos were allowed to survive to E11 or E12, at which time they were killed and processed histologically for examination of cell number in the ciliary ganglion (CG; see below). In another group of embryos, bFGF (3-5 $\mu \mathrm{g}$ ) was injected intramuscularly into the right leg in ovo on E8 and the animals allowed to survive for $24 \mathrm{hr}$ (E9), at which time they were killed, processed histologically, and examined for pyknotic motoneurons in the lumbar spinal cord (see below). Because heparin is known to protect aFGF (and to a lesser extent bFGF) from acid, heat, and protease degradation (Gospodarowicz, 1990), and because heparin or heparin-like molecules modulate biological activity and appear necessary for the functional binding of FGF to its receptors (Klagsbrun and Baird, 1991; Ruoslahti and Yamaguchi, 1991; Savona et al., 1991; Yayon et al., 1991), some of the treatment paradigms noted above included FGF treatment both with and without heparin. When heparin was used, it was administered at either 25 or $50 \mu \mathrm{g}$ per injection.

Radioimmunoassay and in vivo mitogenic assay. In order to examine whether FGF applied to the extraembryonic CAM of the avian egg had access to the embryo, a sensitive two-site radioimmunoassay was used to measure serum levels in the embryonic circulatory system on E8. Thirty minutes following the administration of $10 \mu \mathrm{g}$ or $20 \mu \mathrm{g}$ of bFGF (both with and without $25 \mu \mathrm{g}$ of heparin) onto the CAM, embryos were removed from the egg and decapitated and blood was obtained and pooled from six embryos per group. These samples were centrifuged $(600 \times g$ for $5 \mathrm{~min})$ and the serum collected and stored at $-70^{\circ} \mathrm{C}$. The two-site ELISA assay used was a modification of Sato et al. (1989). Briefly, this assay employed glutaraldehyde-fixed Balb5C/3T3 cells as a heparin matrix to bind FGF in the first reaction and a labeled monoclonal antibody in the second reaction. Specific FGF was determined by subtracting the sample background obtained when the first FGF binding step is carried out in the presence of $10 \mu \mathrm{g} / \mathrm{ml}$ soluble heparin. The minimum sensitivity of this assay is approximately $1 \mathrm{ng} / \mathrm{ml}$ (Sato et al., 1989).

In order to examine the mitogenic effect of FGF on spinal cord cells, an antibody to the thymidine analog 5-bromo-2'-deoxyuridine (BrdU; Becton-Dickinson) was used for immunocytochemical quantitation of proliferation in the lumbar spinal cord (Gratzer, 1982; Hayashi et al., 1988; Miller and Nowakowski, 1988). Embryos were administered bFGF $(5 \mu \mathrm{g})$ onto the CAM in the morning of E8 and E9. One hour after the second treatment on E9, they were given $10 \mu \mathrm{g}$ of BrdU onto the CAM (Sigma) and then killed $4 \mathrm{hr}$ later. The spinal cord was removed and placed in Carnoy's fixative overnight, processed for paraffin histology, sectioned $(10 \mu \mathrm{m})$, and reacted immunohistochemically with the $\mathrm{BrdU}$ antibody (diluted 1:20) using a Vector ABC kit for diaminobenzidine (immunoperoxidase) immunoreactivity. Quantitation was carried out as described below.

Histology, cell counts, and morphometrics. Cell counts of spinal motoneurons, spinal sensory (DRG) and sympathetic ganglion (SG) neurons, and sympathetic preganglionic neurons were obtained from transverse sections $(10-12 \mu \mathrm{m})$ of the entire thoracolumbar region of the embryo. Motoneurons were counted in every tenth section through the entire lumbar spinal cord. Sensory and sympathetic neurons were counted in every fifth section through the third lumbar segmental ganglion (L3), and preganglionic cells were counted in every tenth section through the fifth and sixth thoracic segments (T5-6). Nodose and ciliary ganglia were dissected out and processed independently. In both ganglia, cells were counted in every fifth section. Neurons were also counted in every fifth section through several brain nuclei that have been previously shown to undergo naturally occurring cell death. These included the isthmo-optic nucleus, the cochlear nuclei laminaris and magnocellularis, the trochlear and abducens nuclei, the mesencephalic nucleus of the trigeminal nerve, the isthmo-optic nucleus, and the accessory oculomotor nucleus. All tissues were embedded in paraflin, sectioned, and stained with thionin as described previously (Chu-Wang and Oppenheim, 1978). Only cells that exhibited all of the following characteristics were included in the counts: large soma with substantial cytoplasm, large nucleus, and a single large clump of nucleolar material (Fig. 1). With these criteria, it was not necessary to apply correction factors for double counting (see Oppenheim et al., 1989). Quantitation of nonneuronal (glia and endothelial) cells involved counting all small cells in the lumbar ventral horn or lateral motor column (LMC) in cvery tenth section. These non-neuronal cells were clearly distinguishable from both the large motoneurons and the few smaller interneurons present in the LMC (Fig. 1). Counts of BrdU-labeled cells were made from single transverse sections through segment L4 and included all heavily labeled cells in both the white and gray matter of the entire spinal cord section (Fig. 1). Degenerating (pyknotic) cells were identified using previously established criteria (Chu-Wang and Oppenheim, 1978). Pyknotic cells were counted in every tenth section through the LMC on either E8 or E9, and in every fifth section through CG on E12 following treatment with bFGF (5 $\mu \mathrm{g})$ onto the CAM from E6 to E8 (LMC), or E8 to E12 (CG), or following intramuscular injection on E8 (LMC).

Cell size was assessed by measuring the nuclear diameter or the soma diameter (or both) of CG cells and motoneurons in the lumbar LMC. Only those cells that met all of the same criteria for inclusion in the cell counts (see above) were utilized. Because nuclear diameter is proportionate to soma size among chick spinal motoneurons (R. W. Oppenheim, D. Prevette, and F. Fuller, unpublished observations), this measure is a reasonably accurate index of cell size. The outline of the nucleus or soma was drawn using a drawing tube, and the average of the longest and shortest diameter was estimated using a computerized morphometric program (SIGMASCAN). In all cases of cell counts and morphometric analyses, the observer was unaware (blinded) of the treatment status of each preparation being evaluated.

\section{Results}

\section{Radioimmunoassay and mitogenic assay}

Following the administration of exogenous human recombinant bFGF onto the vascularized CAM of E8 chick embryos, serum levels of immunologically active bFGF were significantly elevated (Table 1). Similar results were obtained regardless of whether bFGF was administered with heparin $(25 \mu \mathrm{g})$ or without. These serum levels are several orders of magnitude higher than the $\mathrm{ED}_{50}$ of the human recombinant bFGF used here for promoting the survival of avian ciliary neurons in vitro (i.e., 50 $\mathrm{pg} / \mathrm{ml}$; F. Fuller, unpublished observations).

BrdU is incorporated into the nuclei of S-phase cells, where it can be identified immunohistochemically by an anti-BrdU monoclonal antibody, and has been demonstrated to be a sensitive and reliable marker of proliferation in the vertebrate CNS, generating data that are in close agreement with those obtained using tritiated thymidine autoradiography (Miller and Nowakowski, 1988; I undy et al., 1991). Following 2 d of treatment with $5 \mu \mathrm{g}$ of bFGF (E8 and E9), the number of BrdU-immunolabeled cells in the lumbar spinal cord was increased by approximately $30 \%$ (Table 2 ). Because partial hydrolysis to denature the DNA is necessary in preparing tissue for BrdU immunohistochemistry, it was not possible to identify distinct cell types in thionin-counterstained tissue. However, it is almost certain that the BrdU-labeled cells were non-neuronal. Studies using tritiated thymidine autoradiography have shown that neuronal proliferation has ceased by E7-E8 in the chick spinal cord (Fujita, 1964; Langman and Haden, 1970; McKay and Oppenheim, 1991). Furthermore, as indicated in Figure 1, many of the BrdU-labeled cells are located in regions devoid of neurons (white matter, dorsal root, glycogen body). Finally, whereas the number of MNs in the LMC was unchanged on E10 following treatment with bFGF (see below), counts of non-neuronal cells in the LMC were significantly increased (Table 2). Therefore, it seems quite likely that bFGF administered onto the CAM had access to cells including neurons in the CNS. Although we consider it unlikely, we cannot exclude the possibility that the amount of FGF in the nervous system was sufficient to have a mitogenic effect on non-neural cells but insufficient for affecting neuronal survival. However, the fact that the serum levels of FGF were 

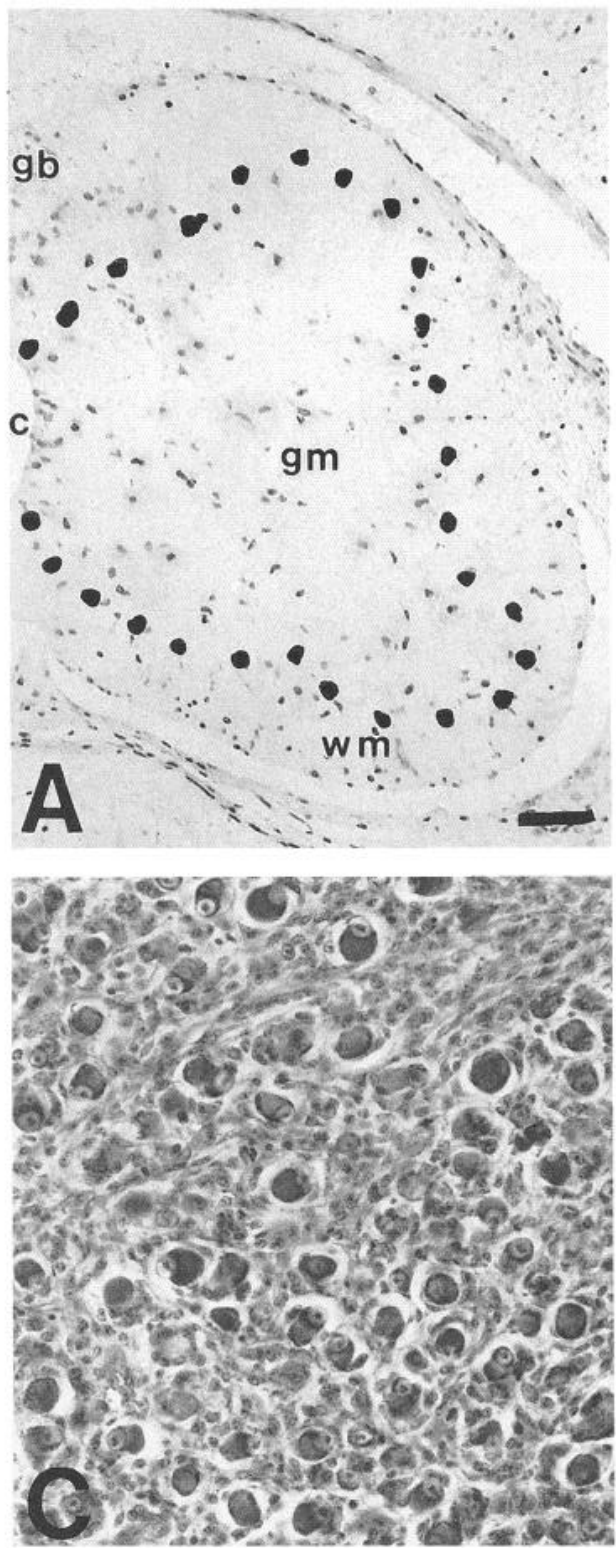

Fioure $1 . A$ and $B$. Transverse frozen sections $(15 \mu \mathrm{m})$ through the lumbar spinal cord of E9 control $(A)$ and bFGF-treated $(B)$ embryos examined with a monoclonal antibody to BrdU. Small dark-stained profiles distributed throughout the sections reflect BrdUlabeled cells in the S-phase of mitosis. $c$, central canal; $d r$, dorsal root; $g b$, glycogen body; $\mathrm{gm}$, gray matter; $w m$, white matter. The large black dots in $A$ indicate the boundary between white and gray matter. Scale bar, $210 \mu \mathrm{m}$. $C$ and $D$, Transverse sections of E15 control $(C)$ and bFGF-treated $(D) C G$ stained with thionin (Nissl stain). $p$, a pyknotic neuron. Scale bar, $45 \mu \mathrm{m}$. $E$ and $F$, Transverse sections through the lumbar ventral horn on $\mathrm{E} 10$ of control $(E)$ and bFGF-treated $(F)$ embryos. Asterisks indicate examples of small, non-neuronal cells included in the cell counts described in Materials and Methods. $m n$, motoneuron. Scale bar, $8 \mu \mathrm{m}$.

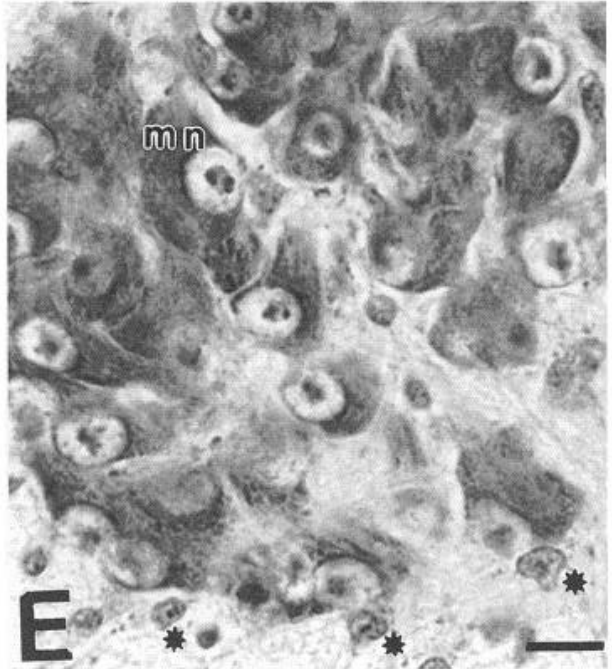

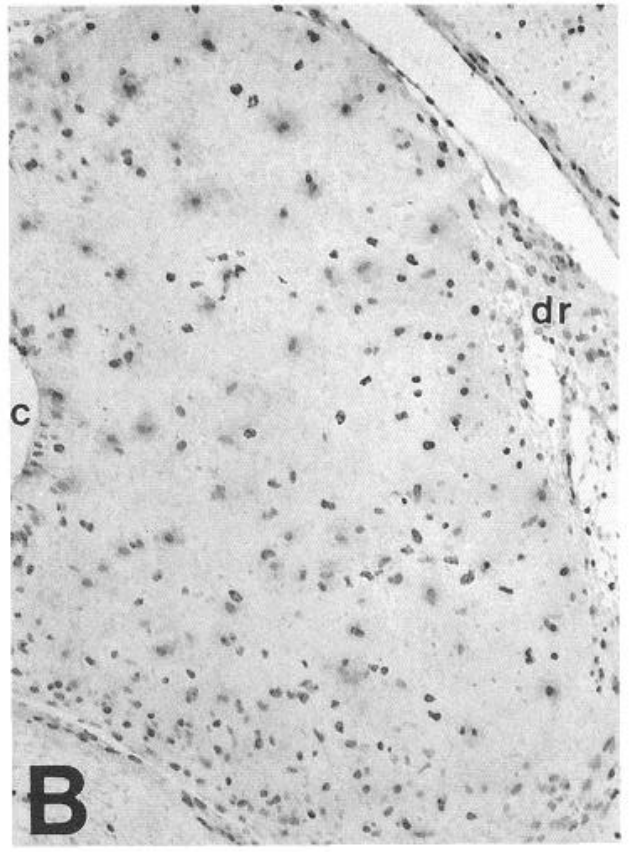
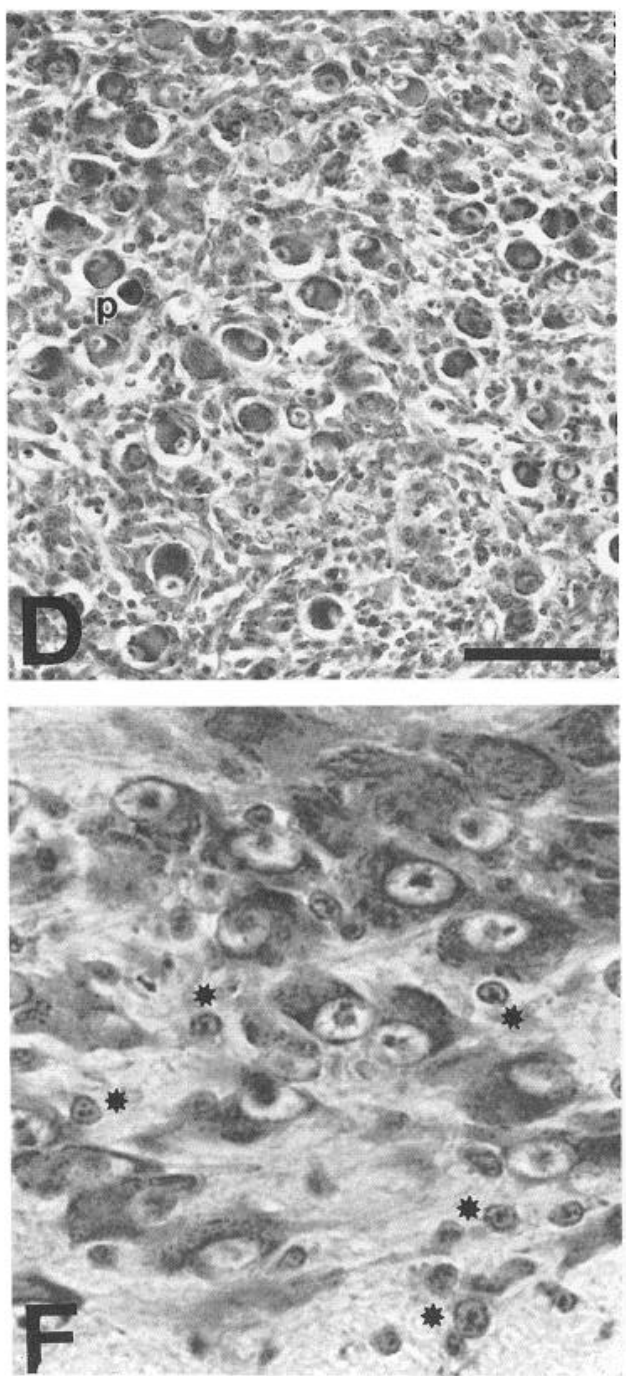


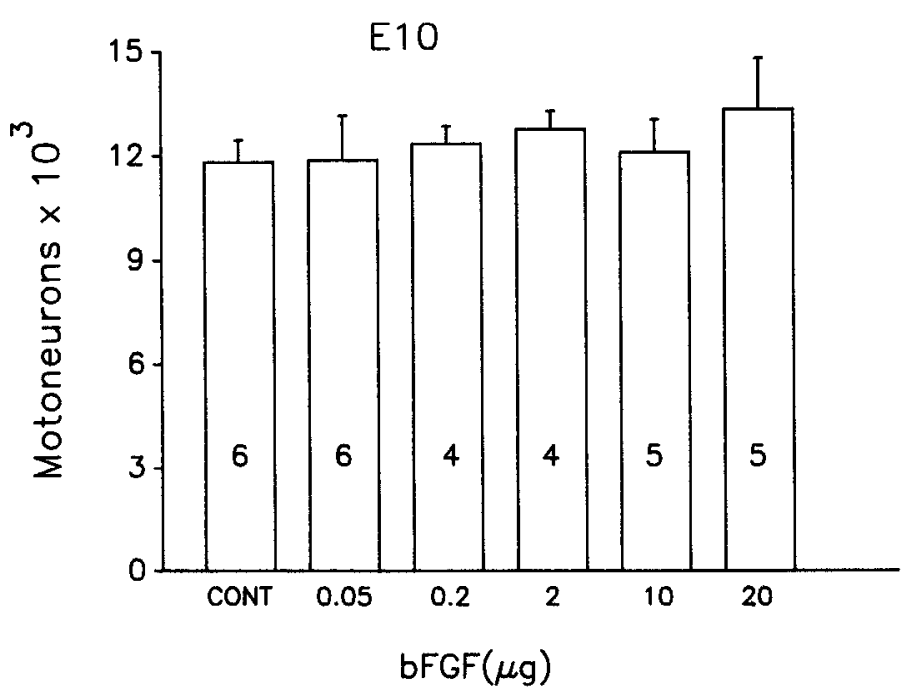

Figure 2. Mean $( \pm \mathrm{SD})$ number of MNs on E10 following treatment with various doses of bFGF from E6 to E9. Numbers in columns are sample sizes.

several orders of magnitude higher than the $\mathrm{ED}_{50}$ of FGF for promoting CG survival in vitro argues strongly against this possibility.

\section{Neuronal numbers}

Treatment in vivo (E6-E9) with a wide range of doses of bFGF had no apparent effect on the survival of spinal MNs irrespective of whether the bFGF was administered with (data not shown) or without heparin (Fig. 2). Heparin alone $(25 \mu \mathrm{g})$ was also ineffective (not shown). Direct injections of bFGF into the hindlimb on E8 failed to reduce the total number of pyknotic MNs present in the lumbar region $24 \mathrm{hr}$ later (control, $84 \pm 8, n=$ 4 , vs. bFGF-treated, $79 \pm 11, n=5$ ). Similarly, in vivo treatment (E9-E14) with several different doses of bFGF was also without effect on the survival of neurons in the CG (Fig. 3, Table 3). Moreover, treatment with bFGF from E8 to E13, following a protocol previously reported to prevent cell death in the chick CG in vivo (Dreyer et al., 1989), was also ineffective in promoting neuronal survival (Fig. 4). Injections of bFGF directly into the vitreous of the eye in ovo on E10-E11 also failed to alter the normal course of cell death in the CG (Table 3). Although aFGF was only administered at a single dose from E6 to E9 or from E9 to E14 ( $5 \mu \mathrm{g} /$ day) in the presence of heparin ( 25 or $50 \mu \mathrm{g}$ ),

Table 1. Two-site radioimmunoassay of serum bFGF levels following in vivo treatment with bFGF in the chick embryo

\begin{tabular}{lc} 
Group & FGF $(\mathrm{ng} / \mathrm{ml})$ \\
\hline Normal serum & $<0.6$ \\
Saline & $<0.6$ \\
Heparin $(25 \mu \mathrm{g})$ & $<0.6$ \\
FGF $(10 \mu \mathrm{g}+$ heparin $)$ & 53.0 \\
FGF $(20 \mu \mathrm{g}+$ heparin) & $>75.0$ \\
FGF $(10 \mu \mathrm{g})$ & 53.0 \\
FGF $(20 \mu \mathrm{g})$ & $>75.0$
\end{tabular}

$n=6$ for all groups. Because serum samples were pooled from all six embryos in each group, it was not possible to determine measures of variance. The values are average serum levels per embryo.

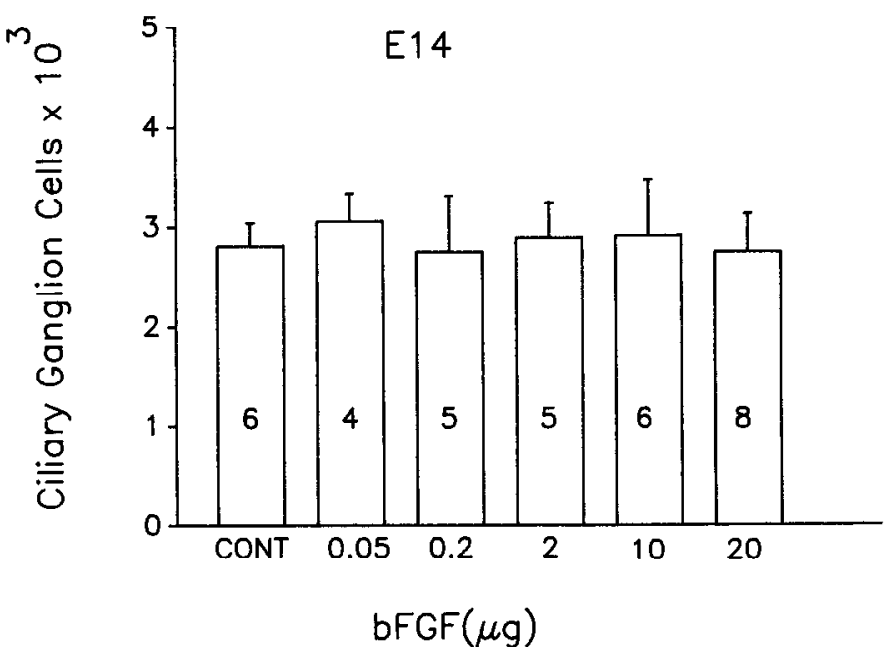

Figure 3. Mean $( \pm$ SD) number of ciliary neurons on E14 following treatment with various doses of bFGF from E9 to E13. Numbers in columns are sample sizes.

it also failed to promote the survival of spinal MNs, DRG cells, CG cells, or several populations of CNS neurons (Fig. 5, Table 4). The lack of a difference in the numbers of pyknotic cells per 1000 healthy neurons provides independent confirmation of the ineffectiveness of bFGF on either MN or CG survival [pyknotic MNs, El0: control, $16.6 \pm 3.8(n=8)$ vs. bFGF, $15.3 \pm 5.1$ $(n=6)$; pyknotic CG, E12: control, $12.3 \pm 3.4(n=5)$ vs. bFGF, $10.9 \pm 3.3(n=5)]$. Finally, treatment with bFGF $(10 \mu \mathrm{g})$ from E6 to E9 also failed to alter the number of surviving neurons in the SG, DRG, and nodose ganglia or in the sympathetic preganglionic nucleus of Terni (Table 5), and treatment from E9 to E14 did not promote survival in several brain nuclei on E15 (Table 4). All of the populations of neurons examined are known to exhibit naturally occurring cell death during the treatment periods (Oppenheim, 1991).

Despite the complete lack of effect of either aFGF or bFGF on neuronal survival, it is still possible that these agents can influence other aspects of growth or differentiation. For instance, FGF has been shown to enhance the cholinergic development of rat spinal cord cells in vitro and chick CG cells in vivo (McManaman et al., 1989; Hill et al., 1991) and NGF is well known to affect neuronal size and process outgrowth (Snider and Johnson, 1989). However, measures of soma and nuclear size among MNs and CG cclls wcre unchanged following treatment with either bFGF or aFGF (Table 6). Furthermore, cytological characteristics of these cells following thionin staining also appeared unaffected by treatment with either aFGF or bFGF (Fig. 1).

\begin{tabular}{lcc}
\hline Table 2. & Effects of bFGF on non-neuronal cells \\
& BrdU-labeled cells & $\begin{array}{l}\text { Non-neuronal } \\
\text { cells in LMC }\end{array}$ \\
\hline Control & $350 \pm 46$ & $18,764 \pm 2041$ \\
& $(16)$ & $(4)$ \\
bFGF & $493 \pm 63^{*}$ & $28,508 \pm 3825^{* *}$ \\
& $(19)$ & $(4)$
\end{tabular}

Values are means \pm SD of numbers of cells; sample sizes are given in parentheses. ${ }^{*} p<0.001 ;{ }^{* *} p<0.01$ ( $t$ tests). 


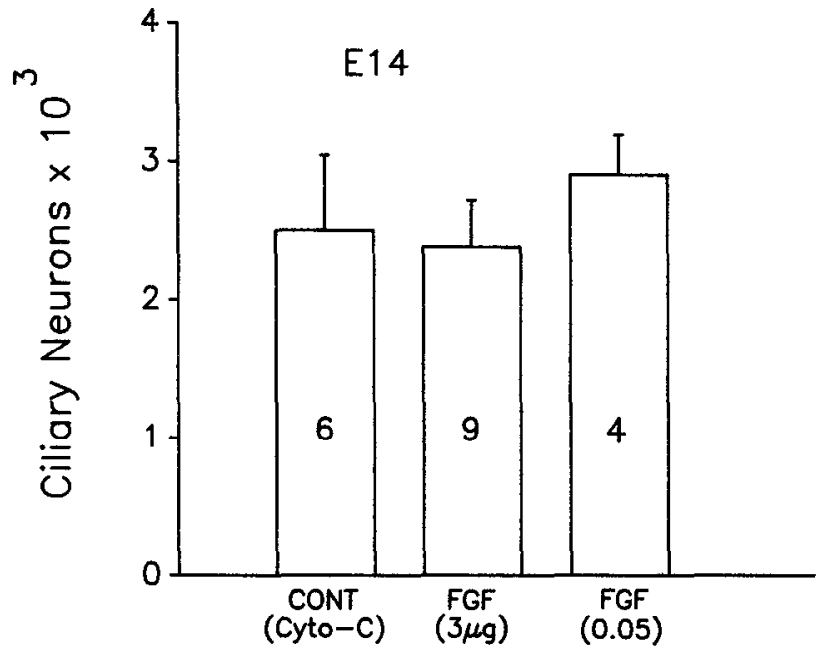

Figure 4. Mean ( + SD) number of ciliary neurons on F.14 following treatment with two doses of bFGF. bFGF or cytochrome $\mathrm{C}(\mathrm{Cyto}-\mathrm{C})$ was administered on E8, E9, E11, and E13 as described in Dreyer et al. (1989). Numbers in columns are sample sizes.

\section{Discussion}

FGF and related heparin-binding polypeptide growth factors have been previously suggested to be candidate molecules that may act as neurotrophic survival agents in the developing nervous system. Evidence in support of this contention comes mainly from in vitro studies in which the survival of a wide variety of neurons is reported to be promoted by these agents (Walicke, 1989; Westermann et al., 1990). However, even when tested in vitro, not all types of neurons exhibit survival effects following treatment with FGF (Rydel and Greene, 1978; Lipton et al., 1988; Stemple et al., 1988; Walicke, 1988; Matsuda et al., 1990). In the chick embryo, some investigators have reported that FGF increases the survival or differentiation of $C G$, sensory ganglion, and SG neurons, as well as spinal MNs in vitro (Unsicker et al., 1987; Arakawa et al., 1990; Eckenstein et al., 1990; Grothe et al., 1991b), whereas other investigators have failed to find an effect of FGF on either cultured chick spinal MNs (Dohrmann et al., 1987; Bloch-Gallego et al., 1991) or cultured neural crest derivatives (Rydel and Greene, 1987; Unsicker et al., 1987; Stemple et al., 1988), including sympathetic, sensory, and chromaffin cells. Although some of these apparent discrepancies can probably be explained by differences in the age of the neurons or other methodological differences, others are more difficult to explain in this way.

Because putative trophic agents may promote neuronal survival in vitro by means that are not normally operative in vivo, we have chosen to examine the effects of FGF on the magnitude of naturally occurring cell death in vivo as an alternative and

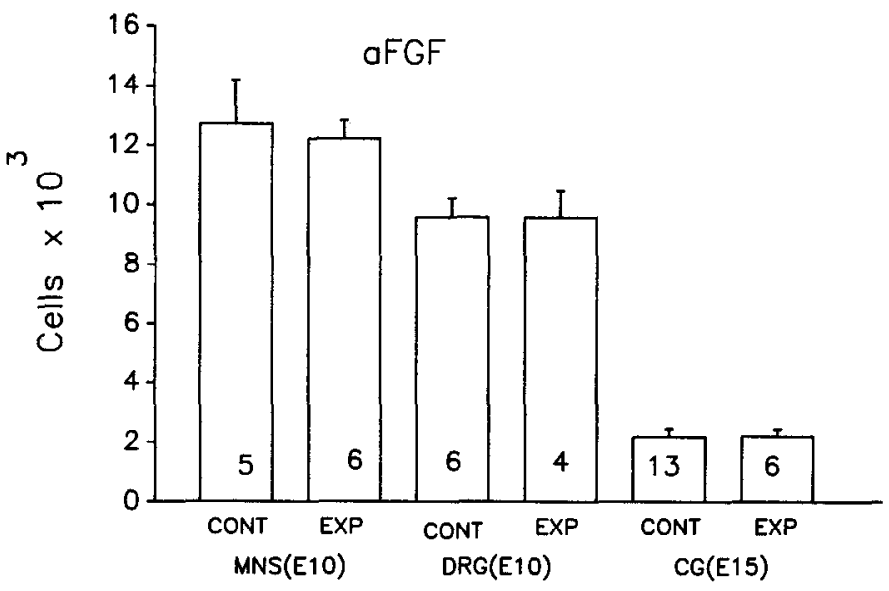

Figure 5. Mean ( $\pm \mathrm{SD}$ ) number of motoneurons (MNS), DRG, and CG neurons following treatment with aFGF $(5 \mu \mathrm{g})$ plus heparin $(50 \mu \mathrm{g})$. Numbers in columns are sample sizes.

more biologically relevant model for neurotrophic activity. One previous study has reported that bFGF treatment in vivo rescues chick ciliary neurons from naturally occurring cell death (Dreyer et al., 1989), a finding that is consistent with the observed survival effects of bFGF on ciliary neurons in vitro (Unsicker et al., 1987; Eckenstein et al., 1990). However, as shown here, we have been unable to replicate this finding (also see Hill et al., 1991). One major apparent difference between our study and that of Dreyer et al. (1989) is that neurons were always counted blind in the present study.

Both FGF protein and FGF receptors and their respective mRNAs are present in the nervous system of developing avian embryos (Mascarelli et al., 1987; Janet et al., 1988; Heuer et al., 1990; Kalcheim and Neufeld, 1990; Mitrani et al., 1990; Schnürch and Risau, 1991; Hondermarck et al., 1992). Chorioallantoic fluid of E9 chick embryos also contains significant levels of biologically active (mitogenic) bFGF (Flamme et al., 1991), and developing limb buds and skeletal muscle also exhibit significant bFGF immunoreactivity (Kalcheim and Neufeld, 1990). Similar results have been reported for the nervous system and skeletal muscle of embryonic and postnatal mouse and rat (Janet et al., 1987; McManaman et al., 1989; Caday et al., 1990; Reid et al., 1990; Wanaka et al., 1990, 1991; Grothe et al., 1991a; Wilcox and Unnerstall, 1991). Thus, FGF and its receptor appear to be present at the appropriate ages and in the appropriate regions in vivo (PNS, CNS, or target regions) to play a role in neuronal survival (but see Heuer et al., 1990). However, it is also possible, even though it is present at the right time and place, that FGF is involved in aspects of neuronal or non-neuronal development other than survival. For example, FGF is known to act as a mitogen for a variety of precursor cell types, including glioblasts, osteoblasts, neuroblasts, myoblasts, capil-

Table 3. Effects of bFGF on ciliary neuron numbers (mean \pm SD)

E12

Control
(saline)

(11)

\section{FGF}

$2 \mu \mathrm{g}$

$3229 \pm 450$

(11)
E14

\begin{tabular}{llcc}
\hline $\begin{array}{l}\text { Control } \\
\text { (saline) }\end{array}$ & $\begin{array}{l}\text { FGF } \\
(5 \mu \mathrm{g})\end{array}$ & $\begin{array}{c}\text { FGF }+ \text { heparin } \\
(5 \mu \mathrm{g}+50 \mu \mathrm{g})\end{array}$ & $\begin{array}{l}\text { Heparin } \\
(50 \mu \mathrm{g})\end{array}$ \\
\hline $\begin{array}{c}2876 \pm 361 \\
(5)\end{array}$ & $\begin{array}{c}2820 \pm 310 \\
(5)\end{array}$ & $\begin{array}{c}2916 \pm 335 \\
(5)\end{array}$ & $\begin{array}{c}2905 \pm 287 \\
(6)\end{array}$ \\
\hline
\end{tabular}

The number of embryos is given in parentheses. 
Table 4. Cell numbers (mean \pm SD) in several brain nuclei on E15 following daily treatment with

bFGF or aFGF $(5 \mu \mathrm{g})$ from E9 to E14

\begin{tabular}{|c|c|c|c|c|}
\hline \multirow[b]{2}{*}{ Nucleus } & \multirow[b]{2}{*}{ Control $(n)$} & \multicolumn{2}{|c|}{ Experimental $(n)$} & \multirow{2}{*}{$\begin{array}{l}\% \text { Normal. } \\
\text { cell loss } \\
\text { between E10 } \\
\text { and E1 } 15^{a}\end{array}$} \\
\hline & & bFGF & $\mathrm{aFGF}$ & \\
\hline $\begin{array}{l}\text { Accessory oculomotor } \\
\text { (Edinger-Westphal) }\end{array}$ & $\begin{array}{c}1155 \pm 186 \\
(4)\end{array}$ & $\begin{array}{l}1080 \perp 150 \\
(6)\end{array}$ & $\begin{array}{l}1030 \pm 163 \\
(5)\end{array}$ & $46 \%$ \\
\hline Isthmo-optic & $\begin{array}{c}7855+932 \\
(4)\end{array}$ & $\begin{array}{l}7710 \pm 1003 \\
(6)\end{array}$ & $\begin{array}{l}7547 \pm 1246 \\
\quad(5)\end{array}$ & $50 \%$ \\
\hline Mesencephalic V & $\begin{array}{c}1442 \pm 203 \\
(4)\end{array}$ & $\begin{array}{l}1367 \pm 185 \\
(6)\end{array}$ & $\begin{array}{l}1356 \pm 393 \\
\quad(5)\end{array}$ & $71 \%$ \\
\hline Magnocellularis & $\begin{array}{c}3523 \pm 576 \\
(4)\end{array}$ & $\begin{array}{c}3646 \pm 497 \\
(6)\end{array}$ & $\begin{array}{l}3345 \pm 531 \\
(5)\end{array}$ & $18 \%$ \\
\hline Laminaris & $\begin{array}{c}1525 \pm 149 \\
(4)\end{array}$ & $\begin{array}{c}1439 \pm 214 \\
(6)\end{array}$ & $\begin{array}{c}1431 \pm 199 \\
(5)\end{array}$ & $38 \%$ \\
\hline Trochlear & $\begin{array}{l}678 \pm 149 \\
(4)\end{array}$ & $\begin{array}{l}751 \pm 122 \\
(6)\end{array}$ & $\begin{array}{l}647 \pm 112 \\
(5)\end{array}$ & $36 \%$ \\
\hline Abducens & $\begin{array}{l}660 \pm 93 \\
(4)\end{array}$ & $\begin{array}{l}705 \pm 87 \\
(6)\end{array}$ & $\begin{array}{l}730 \pm 150 \\
(5)\end{array}$ & $44 \%$ \\
\hline
\end{tabular}

Sample sizes are given in parentheses.

a Normative data on cell death between E10 and E15 are from unpublished observations (R. W. Oppenheim). However, these data are in close agreernent with published data on cell death in these populations (see Oppenheim, 1981, 1991).

lary endothelial cells, hematopoietic cells, and neural crest-derived ncuronal precursors (Pettman et al., 1985; Gensburger et al., 1987; Ferrara et al., 1988; Hatten et al., 1988; Stemple et al., 1988; Frenkel and Singh, 1989; Davis and Stroobant, 1990; Gabbinelli et al., 1990; Gospodarowicz, 1990; McKinnon et al., 1990; Eckenstein et al., 1991; Lundy et al., 1991; Morrison, 1991). Alternatively, FGF may only affect neuronal survival indirectly by increasing the availability of trophic agents derived from some of the above populations of non-neuronal cells (Engele and Bohn, 1991; Petroski et al., 1991). The in vivo model used in the present study has the advantage of being able to detect both direct and indirect effects of FGF on neuronal survival, but it also has the disadvantage of not being able to distinguish between these two modes of action. In view of the general lack of effect of FGF on neuronal numbers observed here, we conclude that in the present context FGF has neither direct nor indirect effects on neuronal survival in vivo.

Because FGF had no effect on the in vivo survival of any of the different populations of neurons examined in the present study, it is conceivable that the human recombinant FGF used here is not biologically active on neurons in the chick embryo. This seems exceedingly unlikely, however, since bFGF is known to be a highly conserved protein (Gospodarowicz, 1990) and at least the bFGF used here does, in fact, promote the survival of

$\overline{\text { Table 5. Neuronal numbers (mean } \pm \text { SD) following in vivo treatment }}$ with bFGF (10 $\mu \mathrm{g})$

\begin{tabular}{lcr} 
Cell type & \multicolumn{1}{l}{ Control } & \multicolumn{1}{l}{ bFGF } \\
\hline Sympathetic (L3) & $10,675 \pm 1011$ & $10,820 \pm 964$ \\
Preganglionic (T5-6) & $3004 \pm 180$ & $3142 \pm 297$ \\
Dorsal Root (L3) & $10,033 \pm 1006$ & $9458 \pm 875$ \\
Nodose & $5317 \pm 621$ & $5195 \pm 572$ \\
\hline
\end{tabular}

$n=5$ for all. chick CG neurons in vitro (see Materials and Methods). Alternatively, the main routc of administration used by us, involving injection onto the CAM, may not provide access of FGF to the embryo. Clearly this is not the case, however, since administration onto the CAM resulted in biologically significant levels of bFGF in embryonic serum as measured by a sensitive twosite radioimmunoassay. Furthermore, embryos treated in this way, exhibited an in vivo mitogenic effect of FGF on spinal cord non-neuronal cells (glia), and this effect was observed both with and without added heparin. This in vivo effect on non-neuronal proliferation supports previous in vitro studies that found a mitogenic effect of FGF on glial precursors (Hatten et al., 1988; Davis and Stroobant, 1990; Gospodarowicz, 1990; Morrison, 1991). Finally, injections of bFGF with and without heparin directly into the embryo in ovo (limb bud or vitreous of the eye) also failed to affect the survival of either spinal MNs or ciliary neurons. In view of these various controls, we conclude that cxogenous FGF administered to the chick embryo in vivo exhibits biological activity in the CNS (mitogenic for non-neuronal

\begin{tabular}{lccc}
\hline Table 6. Cell size following FGF treatment & \\
& $\begin{array}{l}\text { MN }(\mathrm{E} 10) \\
\text { nuclear } \\
\text { diameter }(\mu \mathrm{m})\end{array}$ & $\begin{array}{l}\text { CG }(\mathrm{E} 14) \\
\text { Soma } \\
\text { diameter }(\mu \mathrm{m})\end{array}$ & $\begin{array}{l}\text { Nuclear } \\
\text { diameter }(\mu \mathrm{m})\end{array}$ \\
\hline Control & $7.9 \pm 0.8$ & $14.8 \pm 7.7$ & $6.6 \pm 1.0$ \\
& $(35)$ & $(170)$ & $(184)$ \\
bFGF $^{a}$ & $8.2 \pm 1.1$ & $15.2 \pm 6.5$ & $6.4 \pm 1.4$ \\
aFGF & $(102)$ & $(60)$ & $(182)$ \\
& $8.0 \pm 1.2$ & $14.9 \pm 6.1$ & $6.8 \pm 1.6$ \\
\hline
\end{tabular}

Sample sizes are given in parentheses.

${ }^{a}$ Data were pooled from embryos receiving $0.2,2.0$, and $10.0 \mu \mathrm{g}$ bFGF. There were no significant differences between these groups. 
cells) but is without effect on neuronal survival. Thus, it seems unlikely that FGF is a biologically relevant neurotrophic agent for any of the populations of developing neurons examined here. FGF also did not appear to affect the growth or cytological differentiation of either MNs or CG cells. However, we cannot exclude the possibility that FGF may regulate other aspects of neuronal differentiation. In vitro and in vivo sludies have shown that FGF enhances cholinergic differentiation of spinal cord and ciliary neurons and promotes neuronal growth in a variety of different types of neurons (Walicke et al., 1986; McManaman et al., 1989; Westermann et al., 1990; Grothe et al., 1991; Hill et al., 1991). In view of the lack of effect of FGF on the in vivo survival of either avian MNs or CG cells, it is of some interest that adult rat MNs and postnatal chick $C G$ fail to exhibit retrograde transport of aFGF or bFGF (Ferguson and Johnson, 1991; Hendry and Belford, 1991). By contrast, adult rat spinal MNs express high levels of aFGF mRNA and protein (Elde et al., 1991). MN-derived FGF could serve an autocrine or paracrine function or may be a source of retrograde trophic support for innervating interneurons.

The apparent differences in the in vivo versus in vitro effects of FGF on neuronal survival are, on the face of it, difficult to explain. It is possible that the positive effects in vitro reflect the response of injured neurons that are damaged or injured during processing for tissue culture. According to this view, only injured neurons would be responsive to the survival-promoting effects of FGF. Evidence in support of this view comes from the observation that some of the populations of developing neurons shown here to be unresponsive to FGF in vivo respond to FGF following injury in the adult animal (Otto et al., 1987; Sievers et al., 1987; Blottner et al., 1989). Moreover, bFGF protein and mRNA are rapidly increased in areas adjacent to a brain lesion in adult rats (Frautschy et al., 1991). In addition, we have found that bFGF treatment in vivo can prevent the induced death of spinal MNs following deafferentation in the chick embryo (Okado and Oppenheim, 1984; Yin et al., 1991), cven though, as reported here, FGF has no effect on the naturally occurring death of spinal MNs. One interpretation of these results is that some populations of neurons may change their trophic dependency from non-FGF to FGF proteins between embryogenesis and maturity (e.g., Barde et al., 1988). It is also possible that developing neurons do require FGF for survival but that they develop in vivo in the presence of saturating concentrations of endogenous FGF such that their requirement is fulfilled and therefore additional exogenous FGF is incffcetive. However, if this were the case, then there should be no naturally occurring cell death. Because aFGF and bFGF both lack a hydrophobic signal sequence required for secretion by the classical secretory pathway, it is also conceivable that these agents are only released in sufficient amounts to promote neuronal survival following tissue or cell injury. Accordingly, the present results as well as previous studies indicate that FGF may not be a biologically relevant trophic agent for the survival and maintenance of either developing or mature intact neurons. Rather, FGF may only become effective following neuronal damage and may therefore be a plausible candidate as a pharmacological, therapeutic agent for promoting the survival of neurons at risk following injury, in genetic mutations, or in neurodegenerative disease. Injured neurons may upregulate the expression of FGF or other neurotrophic factor receptors.

In conclusion, despite the increased serum levels of FGF and the significant mitogenic effect on non-neuronal cells in the spi- nal cord of chick embryos following in vivo treatment with FGF, FGF failed to alter the survival or differentiation of several populations of neurons that exhibit naturally occurring or programmed neuronal death. These include spinal MNs, SG and parasympathetic ganglion cells, spinal sympathetic preganglionic cells, sensory neurons in the DRG and nodose ganglia, and several populations of neurons in the brain. On the basis of these consistently negative data, we conclude that FGF is unlikely to be a biologically relevant neurotrophic agent for the survival of developing neurons in the avian embryo.

\section{References}

Arakawa Y, Sendtner M, Thoenen H (1990) Survival eflect of ciliary neurotrophic factor (CNTF) on chick embryonic motoneurons in culture: comparison with other neurotrophic factors and cytokines. J Neurosci 10:3504-3515.

Barde YA, Edgar D, Thoenen H (1980) Sensory neurons in culture: changing requirements for survival factors during embryonic development. Proc Natl Acad Sci USA 77:1199-1203.

Barotte C, Erlancher F, Ebel A, Labourdette G, Sensenbrenner M, Will B (1989) Effects of basic fibroblast growth factor (bFGF) on choline acetyltransferase activity and astroglial reaction in adult rats after partial fimbria transection. Neurosci Lett 101:197-202.

Biedermann JA, McHalffey C, Davies DL, Skinner J, Skinner RD, Garcia-Rill E (1991) The pedunculopontine nucleus: fibroblast growth factor induced survival in vitro and receptor localization in vivo. Anat Rec 229:10A.

Bloch-Gallego E, Huchet M, El M'Hamdi H, Xie FK, Tanaka H, Henderson CE (1991) Survival in vitro of motoneurons identified or purified by novel antibody-based methods is selectively enhanced by muscle-derived factors. Development 111:221-232.

Blottner D, Westermann R, Grothe C, Böhlen P, Unsicker K (1989) Basic fibroblast growth factor in the adrenal gland: possible trophic role for preganglionic neurons in vivo. Eur J Neurosci 1:471-478.

Burgess WH, Macaig T (1989) The heparin-binding (fibroblast) growth factor family of proteins. Annu Rev Biochem 58:575-606.

Caday CG, Klagsbrun M, Fanning PJ, Mirzabegian A, Finkelstein SP (1990) Fibroblast growth factor (FGF) levels in the developing rat brain. Dev Brain Res 52:241-246.

Cao Y, Pettersson R (1990) Human acidic fibroblast growth factor over-expressed in insect cells is not secreted into the medium. Growth Factors 3:1-13.

Chu-Wang IW, Oppenheim RW (1978) Cell death of motoncurons during development: I. A light and electron microscopic study of naturally occurring cell loss during development. J Comp Neurol 177: 33-58.

Davis JB, Stroobant P (1990) Platelet-derived growth factors and fibroblast growth factors are mitogens for rat Schwann cells. J Cell Biol 110:1353-1360.

Dohrmann U, Edgar D, Thoenen H (1987) Distinct neurotrophic factors from skeletal muscle and the central nervous system interact synergistically to support the survival of cultured embryonic spinal motor neurons. Dev Biol 124:145-152.

Dreyer D, Lagrange A, Grothe C, Unsicker K (1989) Basic fibroblast growth factor prevents ontogenetic neuron death in vivo. Neurosci Lett 99:35-38.

Eckenstein FP, Esch F, Holbert T, Blacher RW, Nishi R (1990) Purification and characterization of a trophic factor for embryonic peripheral neurons: comparison with fibroblast growth factors. Neuron 4:623-631

Eckenstein FP, Shipley GD, Nishi R (1991) Acidic and basic fibroblast growth factors in the nervous system: distribution and differential alteration of levels after injury of central versus peripheral nerve. $J$ Neurosci 11:412-419.

Elde R, Cao Y, Cintra A, Brelje T, Pelto-Huikko M, Juntilla T, Fuxe K, Petterson R, Hökfelt T (1991) Prominent expression of acidic fibroblast growth factor in motor and sensory neurons. Neuron 7: 349-364.

Engele J, Bohn MC (1991) The neurotrophic effects of fibroblast growth factors on dopaminergic neurons in vitro are mediated by mesencephalic glia. J Neurosci 11:3070-3078.

Faktorovich EG, Steinberg RH, Yasamura D, Matthes MT, LaVail MM 
(1990) Photoreceptor degeneration in inherited retinal dystrophy delayed by basic fibroblast growth factor. Nature 347:83-86.

Ferguson IA, Johnson EM (1991) Fibroblast growth factor receptorbearing neurons in the CNS: identification by receptor-mediated retrograde transport. J Comp Neurol 313:693-706.

Ferrara N, Onsley F, Gospodarowicz D (1988) Bovine brain astrocytes express basic fibroblast growth factor, a neurotrophic and angiogenic mitogen. Brain Res 462:223-232.

Flamme I, Schulze-Osthoff K, Jacob HJ (1991) Mitogen activity of chicken chorioallantoic fluid is temporally correlated to vascular growth in the chorioallantoic membrane and related to fibroblast growth factors. Development 111:683-690.

Frautschy SA, Walicke PA, Baird A (1991) Localization of basic fibroblast growth factor and its mRNA after CNS injury. Brain Res 553:291-299.

Frenkel SR, Singh IJ (1989) The effect of fibroblast growth factor on chick embryo osteogenesis. Anat Rec 223:40A.

Fujita S (1964) Analysis of neuron differentiation in the central nervous system by tritiated thymidine autoradiography. J Comp Neurol $22: 311-327$

Gabbinelli M, Sargiacomo M, Pelosi E, Testa U, Isacehi G, Peschle C (1990) Pure human hematopoietic progenitors: permissive action of basic fibroblast growth factor. Science 249:1561-1564.

Gensburger C, Labourdette G, Sensenbrenner M (1987) Brain fibroblast growth factor stimulates the proliferation of rat neuronal precursor cells in vitro. FEDS Lett 217:1-5.

Gospodarowicz D (1990) Fibroblast growth factor and its involvement in developmental processes. Curr Top Dev Biol 24:57-93.

Gratzner HG (1982) Monoclonal antibody to 5-bromo and 5-iododeoxyuridine: a new reagent for DNA replication. Science 218:474475.

Grothe C, Zachman K, Unsicker K (1991a) Basic FGF-like immunoreactivity in the developing and adult rat brainstem. J Comp Neurol 305:328-336.

Grothe C, Wewetzer K, Lagrange A, Unsicker K (1991b) Effects of basic fibroblast growth factor on survival and choline acetyltransferase development of spinal cord neurons. Dev Brain Res 62:257-261.

Hatten ME, Lynch M, Rydel RE, Sanchez J, Silverstein JJ, Moscatelli O, Rifkin DB (1988) In vitro neurite extension by granule neurons is dependent upon astroglial-derived fibroblast growth factor. Dev Biol 125:280-289.

Hayashi Y, Koike M, Matsutami M, Hoshino T (1988) Effects of fixation time and enzymatic digestion on immunohistochemical demonstration of bromodeoxyuridine in formalin-fixed, paraffin-embedded tissue. J Histochem Cytochem 36:511-514.

Hendry IA, Belford DA (1991) Lack of retrograde axonal transport of the heparin-binding growth factors by chick ciliary neurons. Int J Dev Neurosci 9:243-250.

Heuer JG, von Bartheld CS, Kinoshita Y, Evers PC, Bothwell M (1990) Alternating phases of FGF receptor and NGF receptor expression in the developing chick nervous system. Neuron 5:283-296.

Hill CE, Belford DA, Godovac-Zimmerman J, Hendry IA (1991) Class 1 heparin binding growth factor promotes the differentiation but not the survival of ciliary neurons in vivo. Dev Brain Res 63:13-19.

Hondermarck H, Court J, Dauchel MC, Barritault D, Boilly B (1992) High and low affinity membrane binding sites for fibroblast growth factors in the developing chick brain. Neurosci Lett 134:247-252.

Janet T, Miehe M, Pettman B, Labourdette G, Sensenbrenner M (1987) Ultrastructural localization of fibroblast growth factor in neurons of rat brain. Neurosci Lett 80:153-157.

Janet T, Grothe C, Pettmann B, Unsicker K, Sensenbrenner M (1988) Immunocytochemical demonstration of fibroblast growth factor in cultured chick and rat neurons. J Neurosci Res 19:195-201.

Kalcheim C (1989) Basic fibroblast growth factor stimulates survival of non-neuronal cells developing from trunk neural crest. Dev Biol 134:1-10.

Kalcheim C, Neufeld G (1990) Expression of basic fibroblast growth factor in the nervous system of early avian embryos. Development 109:203-215.

Klagsbrun M, Baird A (1991) A dual receptor system is required for basic fibroblast growth factor activity. Cell 67:229-231.

Langman J, Haden CC (1970) Formation and migration of neuroblasts in the spinal cord of the chick embryo. J Comp Neurol 138:419-432.

Lipton SA, Wagner JA, Madison RD, D'Amore PA (1988) Acidic fibroblast growth factor enhances regeneration of processes by post- natal mammalian retinal ganglion cells in culture. Proc Natl Acad Sci USA 85:2388-2392.

Lundy MW, Hendrix T, Wergedal JE, Baylink DJ (1991) Growth factor-induced proliferation of osteoblasts measured by bromodeoxyuridine immunocytochemistry. Growth Factors 4:257-264.

Mascarelli F, Raulais D, Couris MF, Courtois Y (1987) Characterization of acidic and basic fibroblast growth factors in brain, retina and vitreous of chick embryo. Biochem Biophys Res Commun 146: 478-486.

Matsuda S, Saito H, Nishigama N (1990) Effect of basic fibroblast growth factor on neurons cultured from various regions of postnatal rat brain. Brain Res 520:310-316.

Mattson MP, Rychlik B (1990) Glia protect hippocampal neurons against excitatory amino acid-induced degeneration: involvement of fibroblast growth factor. Int J Dev Neurosci 8:399-415.

McKay SE, Oppenheim RW (1991) Lack of evidence for cell death among avian spinal cord interneurons during normal development and following removal of targets and afferents. J Neurobiol 22:721733.

McKinnon RD, Matsui T, Dubois-Daleg M, Aaronson SA (1990) FGF modulates the PDGF-driven pathway of oligodendrocyte development. Neuron 5:603-614.

McManaman J, Crawford F, Clark R, Richker J, Fuller F (1989) Multiple neurotrophic factors from skeletal muscle: demonstration of effects of basic fibroblast growth factor and comparisons with the 22-kilodalton choline acetyltransferase development factor. J Neurochem 53:1763-1771.

McManaman JL, Oppenheim RW, Prevette D, Marchetti D (1990) Rescue of motoneurons from cell death by a purified skeletal muscle polypeptide: effects of the ChAT development factor, CDF. Neuron 4:891-898.

Miller MW, Nowakowski RS (1988) Use of bromodeoxyuridine-immunohistochemistry to examine the proliferation, migration and time of origin of cells in the central nervous system. Brain Res 457:44-52.

Mitrani E, Gruenbaum Y, Shohat H, Ziv T (1990) Fibroblast growth factor during mesoderm induction in the early chick embryo. Development 109:387-393.

Morrison RS (1991) Suppression of basic fibroblast growth factor expression by antisense oligodeoxynucleotides inhibits the growth of transformed human astrocytes. J Biol Chem 266:728-734.

Okado N, Oppenheim RW (1984) Cell death of motoneurons in the chick embryo. IX. The loss of motoneurons following removal of afferent inputs. J Neurosci 4:1639-1652.

Oppenheim RW (1981) Neuronal cell death and some related regressive phenomena during neurogenesis. A selective historical review and progress report. In: Studies in developmental neurobiology: essays in honor of Viktor Hamburger (Cowan WM, ed), pp 74-133. New York: Oxford University Press.

Oppenheim RW (1991) Cell death in the developing nervous system. Annu Rev Neurosci 14:453-501.

Oppenheim RW, Haverkamp LJ, Prevette D, McManaman JL, Appel SH (1988) Reduction of naturally occurring motoneuron death in vivo by a target-derived neurotrophic agent. Science 240:919-922.

Oppenheim RW, Cole T, Prevette D (1989) Early regional variations in motoneuron numbers arise by differential proliferation in the chick embryo spinal cord. Dev Biol 133:468-474.

Oppenheim RW, Plevette D, Fuller F (1990) In vivo treatment with basic FGF does not alter naturally occurring neuronal death. Soc Neurosci Abstr 16:1135.

Oppenheim RW, Prevette D, Yin Q-W, Collins F, McDonald J (1991) Control of embryonic motoneuron survival in vivo by ciliary neurotrophic factor. Science 251:1616-1618.

Otto D, Unsicker K (1990) Basic FGF reverses chemical and morphological deficits in the nigrostriatal system of MPTP-treated mice. J Neurosci 10:1912-1921.

Otto D, Unsicker K, Grothe C (1987) Pharmacological effects of nerve growth factor and fibroblast growth factor applied to the transectioned sciatic nerve on neuron death in adult rat dorsal root ganglia. Neurosci Lett 83:156-160.

Petroski RE, Grierson JP, Choi-Kwon S, Geller HM (1991) Basic fibroblast growth factor regulates the ability of astrocytes to support hypothalamic neuronal survival in vitro. Dev Biol 147:1-13.

Pettman B, Weibel M, Sensenbrenner M, Labourdette G (1985) Purification of two astroglial growth factors from bovine brain. FEBS Lett 189:102-108. 
Reid HH, Wilks AF, Bernard O (1990) Two forms of the basic fibroblast growth factor receptor-like mRNA are expressed in the developing mouse brain. Proc Natl Acad Sci USA 87:1596-1600.

Ruoslahti E, Yamaguchi Y (1991) Proteoglycans as modulators of growth factor activities. Cell 64:867-869.

Rydel RE, Greene I A (1987) Acidic and basic fibroblast growth factors promote stable neurite outgrowth and neuronal differentiation in cultures of PC12 cells. J Neurosci 7:3639-3653.

Sato Y, Murphy PR, Sato R, Friesen HG (1989) Fibroblast growth factor release by bovine endothelial cells and human astrocytoma cells in culture is density dependent. Mol Endocrinol 3:744-748.

Savona C, Chambaz E, Feige J (1991) Proteoheparan sulfates contribute to the binding of basic FGF to its high affinity receptors on bovine adrenocortical cells. Growth Factors 5:273-282.

Schnürch H, Risau W (1991) Differentiating and mature neurons express the acidic fibroblast growth factor gene during chick neural development. Development 111:1143-1154.

Sievers J, Hausmann B, Unsicker K, Berry M (1987) Fibroblast growth factors promote the survival of adult rat retinal glanglion cells after transection of the optic nerve. Neurosci Lett 76:157-162.

Snider WD, Johnson EM (1989) Neurotrophic molecules. Ann Neurol 26:489-506.

Stemple DL, Mahanthappa NK, Andcrson DJ (1988) Basic FGF induces neuronal differentiation, cell division, and NGF dependence in chromaffin cells: a sequence of events in sympathetic development. Neuron 1:517-525.

Sweetnam PM, Sanon HR, White LA, Brass BJ, Jaye M, Whittemore SR (1991) Differential effects of acidic and basic fibroblast growth factors on spinal cord cholinergic, GABAergic and glutamatergic neurons. J Neurochem 57:237-249.

Unsicker K, Reichert-Preibsch H, Schmidt R, Pettmann B, Labourdette G, Sensenbrenner M (1987) Astroglial and fibroblast growth factor have neurotrophic functions for cultured peripheral and central nervous system neurons. Proc Natl Acad Sci USA 84:5459-5463.

Wagner JA (1991) The fibroblast growth factors: an emerging family of neural growth factors. Curr Top Microbiol Immunol 165:95-118.

Walicke PA, Cowan WM, Ueno N, Baird A, Guillemin R (1986) Fibroblast growth factor promotes survival of dissociated hippocampal neurons and enhances neurite extension. Proc Natl Acad Sci USA 83:3012-3016.

Walicke PA (1988) Basic and acidic fibroblast growth factors have trophic effects on neurons from multiple CNS regions. J Neurosci 8: 2618-2627.

Walicke PA (1989) Novel neurotrophic factors, receptors and oncogenes. Annu Rev Neurosci 12:103-126.

Wanaka A, Johnson EM, Milbrandt J (1990) Localization of FGF receptor mRNA in the adult rat central nervous system by in situ hybridization. Neuron 5:267-281.

Wanaka A, Milbrandt J, Johnson F.M (1991) Expression of FGF receptor gene in rat development. Development 111:455-468.

Westermann R, Grothe C, Unsicker K (1990) Basic fibroblast growth factor (bFGF), a multifunctional growth factor for neuroectodermal cells. J Cell Sci 13:97-117.

Wilcox BJ, Unnerstall JR (1991) Expression of acidic fibroblast growth factor mRNA in the developing and adult rat brain. Neuron 6:397409.

Yayon A, Klagsbrun M, Esko JD, Leder P, Ornitz DM (1991) Cell surface, heparin-like molecules are required for binding of basic fibroblast growth factor to its high affinity receptor. Cell 64:841-848.

Yin QW, Prevette D, Oppenheim RW, Van Eldik L (1991) Brain extract and glia-derived trophic agents prevent deafferentation-induced motoneuron death in the chick embryo. Soc Neurosci Abstr $17: 1123$ 